\title{
The flow of soul: a sociological study of generosity in England and Wales (2001-2011)
}

Link to publication record in Manchester Research Explorer

\section{Citation for published version (APA):}

$\mathrm{Li}, \mathrm{Y}$. (2015). The flow of soul: a sociological study of generosity in England and Wales $(2001-2011)$. In The Handbook of Research Methods and Applications on Social Capital (pp. 40-59). Edward Elgar Publishing Ltd.

\section{Published in:}

The Handbook of Research Methods and Applications on Social Capital

\section{Citing this paper}

Please note that where the full-text provided on Manchester Research Explorer is the Author Accepted Manuscript or Proof version this may differ from the final Published version. If citing, it is advised that you check and use the publisher's definitive version.

\section{General rights}

Copyright and moral rights for the publications made accessible in the Research Explorer are retained by the authors and/or other copyright owners and it is a condition of accessing publications that users recognise and abide by the legal requirements associated with these rights.

\section{Takedown policy}

If you believe that this document breaches copyright please refer to the University of Manchester's Takedown Procedures [http://man.ac.uk/04Y6Bo] or contact uml.scholarlycommunications@manchester.ac.uk providing relevant details, so we can investigate your claim.

\section{OPEN ACCESS}




\section{The flow of soul: a sociological study of generosity in England and Wales (2001-2011) Yaojun $\mathrm{Li}$}

\section{INTRODUCTION}

The free and bounteous giving of one's time, effort and treasures for good causes and for the benefit of others is an important indicator of civic health in our national life. The time and effort devoted to civic activities, the time and care given to the weak, feeble and others in need beyond one's kin, and the money donated to charitable causes are all manifestations of generosity in society. How are the three domains of generosity related to one another in their patterns and trends in British society? Which socio-demographic factors are most strongly associated with pro-social behaviours? Did the economic recession that started in 2008 have any notable effect on formal and informal social involvement and altruistic behaviour? And to what extent is the pattern of charitable giving in Britain similar to or different from that in the US?

In this analysis, we try to address these questions by analysing the three domains of generosity in England and Wales and exploring their socioeconomic-cultural determinants. Using the Home Office Citizenship Survey (HOCS) covering a period of ten years (2001-11), we find generally high, albeit somewhat falling, rates in volunteering, helping and giving, but the amounts of money given to charitable causes remained at a fairly similar level in spite of the economic crisis that started in 2008. We also find strong class and income effects in the three domains, but ethno-religious effects are weak. People in higher class and income positions tend to give more money in absolute terms but with the exception of own-account workers, who tend to give more, overall class differences in relative giving are negligible among givers and have a positive relationship among all respondents, but the relationship between income and relative giving is negative. In terms of net effects, class differences in the rates of volunteering, helping and giving were the most salient, followed by income differences, and remained so in absolute and relative giving. The differences in the patterns of class and income giving call for an exploration of interaction effects, and further analysis in this regard shows that people in higher class but lower income positions were much more generous than their well-off class peers. Our findings show little resemblance to the 'flat-line', 'U-shape' or inverse class effects in giving as found in the US literature although there was some support for the thesis of religious network effects. On the whole, the British people are quite generous but how to persuade the most advantaged to give more to charitable causes is a challenge to the government and fundraising organizations.

\section{File supplied to Li - Not for distribution}




\section{LITERATURE REVIEW}

Social scientists have long observed a close link between social involvement and philanthropic behaviour. Nearly two hundred years ago, Tocqueville noted with amazement how Americans 'of all ages, all stations in life, and all types of disposition are forever forming associations' (1835 [1965]: 513), and he went on to say that it is an enlightened self-love which 'continually leads them to help one another and disposes them to freely give part of their time and wealth for the good of the state' (1835 [1965]: 526). Further evidence in this regard was provided by Almond and Verba (1965) who found a close relationship between generosity, social trust and political engagement. In the last few decades, various studies have provided still further evidence on this. For instance, Amato (1990), Putnam (2000) and Putnam and Campbell (2010) all find that social networks are closely related to and may be even better predictors of philanthropic behaviour than income levels. There may, however, be differences between giving and volunteering in the US and other countries. For instance, Wright (2002: 413) argues that while for Americans 'giving and volunteering are significant components of civic involvement', in Britain 'giving is peripheral to civic responsibility'.

The most systematic study on pro-social behaviour involving volunteering and giving in the US is arguably that conducted by Putnam (2000) and Putnam and Campbell (2010). Documenting the patterns and trends of civic life in the US in the last fifty years, Putnam concludes that most forms of formal and informal social involvement declined, and charitable giving fell consistently, from the mid-1960s to the 2000s, most sharply in the Catholic giving but also noticeably in the Protestant and United Way giving (Putnam, 2000: 125-7). Even though the overall level of giving declined, there is still a close relationship between religiosity and giving. Putnam and Campbell (2010: 449) show that the most religious fifth of the population give nearly 7 per cent of their annual income to religious and non-religious causes, around four times as much as that by the least religious fifth.

Putnam also holds that although religion is an important reason for philanthropic deeds, it is the social connection formed through religious activities that is the causal or more powerful factor of philanthropic behaviour. Social and particularly religious networks take precedence over other manifestations of social capital such as trust and reciprocity because they are the root of social resources. Adopting Dewey's distinction between doing with and doing for, Putnam holds that social connection in formal and informal activities (doing with) is the defining feature of social capital, whilst charitable giving (doing for) is an outcome of such connectedness. According to him, social and religious connections have channelling and fostering effects on altruistic behaviour. They 'provide the channels through which we recruit one another for good deeds, and . . foster norms of reciprocity that encourage attention to others' welfare' (Putnam, 2000: 117). Bridging ties formed through religious activities with people in different social positions and with different ethnic/racial identities have more powerful effects than altruistic attitudes, financial capital or psychological traits in influencing pro-social behaviour, which remains strong even when demographic factors are taken into account (Putnam, 2000, ch. 7; Putnam and Campbell, 2010, ch. 12; see also Piliavin and Charng, 1990).

As Putnam's main interests are in the stock of social capital, socioeconomic factors are given less attention in his analysis. It is, for instance, difficult to ascertain in his work the

\section{File supplied to Li - Not for distribution}


relative effects of income, class, or cultural (ethno-religious) identity on, or the mutual influences of, joining, helping or giving. Other studies are less comprehensive in scale but are more focused on the socioeconomic impacts on giving. Here we give a brief account of three findings relating to 'flat-line', 'U-shape' and negative class giving which are of direct relevance to the present study.

Schervish and Havens (1995) find a 'flat-line' relationship between income and giving. They argue that, contrary to the popular myth that the poor tend to give more, there is little difference in giving among different income groups. This, they hold, is because most of the earlier studies failed to take into account the different propensities for giving between the poor and the wealthy. Once non-contributors are included in the analysis, relative giving (that is, the amount given as a fraction of the household incomes) is roughly the same at all income levels. From this, they conclude that 'generosity is not strongly related to income and, hence, must be related to other social and personal characteristics that cut across the financial spectrum. Searching for these positive and perhaps class-blind sources of generosity, rather than perpetuating a questionable imagery, should henceforth be the subject of our deliberations' (Schervish and Havens, 1995: 90, emphasis added). It is noted here that the authors only looked at the income effects but were using income and class in equivalent terms. Yet their call for the inclusion of non-contributors in analysis will be duly heeded in the present study, which will also take income and class as separate rather than as conjoint measures.

Challenging the 'flat-line' thesis, James and Sharpe (2007) show a 'U-shaped' relationship between income and giving. They find that both the poor and the rich tend to give more and it is those in middle-income bands who tend to give less. Yet, as with Schervish and Havens (1995), their analysis does not include the effects of other socio-cultural factors, such as class.

Contesting these claims and using an experimental approach, Piff et al. (2012) find that people in lower classes are more generous than those in higher classes. The reason, they hold, is that the former have a greater commitment to egalitarian values and are more compassionate but the latter have a greater proclivity to act 'unethically' (Piff et al., 2012: 4086). Since their analysis is based on a small online survey $(\mathrm{N}=90)$ and since class is derived from subjective SES (Socio-Economic Status), the finding may be due to a perceived linkage between lower-class status and higher propensity of giving. We shall investigate whether this claim of negative class giving holds at the population level in Britain.

While US research on social capital takes the lead, that in Britain is not far behind. Here the focus is not only on trends but also on the stratification basis. For instance, Hall (1999) argues that civic life in Britain is healthy, ${ }^{1}$ albeit with a growing social division. The second part of the claim has received much support (Li et al., 2003, 2005; Li and Marsh, 2008; Li, 2010; Sturgis et al., 2010) but the first part has been subject to much contest as researchers have found smaller friendship ties (Pahl and Pevalin, 2005), reduced political involvement (Grenier and Wright, 2006), and faltering charitable giving (Pharoah, 2009; CAF/NCVO, 2010; Smith, 2012).

Whilst time and money given to good causes are two sides of the same coin, the flow of soul, as Alexander Pope felicitously put it, academic research tends to treat them separately. Sociologists and political scientists tend to focus on helping and joining (Hall, 1999; Putnam, 2000; Pevalin and Rose, 2003; Li et al., 2003, 2005; Li and Marsh, 2008),

\section{File supplied to Li - Not for distribution}


while economists, social psychologists and voluntary sector researchers have concentrated on giving - reasons, modes and amounts of charitable donation (Lee et al., 1995; Khanna et al., 1995; Khanna and Sandler, 2000; Pharoah and Tanner, 1997; Banks and Tanner, 1999; Wright, 2002; Bekkers and Wiepking, 2007; Collett and Morrissey, 2007; Pharoah, 2009; DCLG, 2010a, 2010b; Wagner, 2012). The insights gained from each perspective are no doubt important for our understanding of the causes, manifestations and consequences of people's disposition toward and practice of generosity, but it would be equally or more important if the two fields of research can be bridged, a view expressed in Schervish and Havens (1997) and which is endorsed here.

With regard to giving, there are considerable contextual differences between the US and Britain that should be taken into account even though the present study is not a comparative one. For example, religious giving is usually found to be very important in the US (Lincoln et al., 2008; Putnam and Campbell, 2010) but, unlike the highly religious Americans, most Britons are neither believing nor belonging (Voas and Crockett, 2005). Religion is closely related to ethnicity but the main ethnic groups are different in the two countries. Most importantly for our present purposes, measures of social class are different in the empirical studies in the two countries. US researchers tend to use the SES whilst British researchers use the official National Statistics Social-economic Classification (NSSeC). The former is an indicator of social standing in society whereas the latter takes account of both employment and occupational statuses which, as we are going to see, could capture the giving propensity for certain groups such as the self-employed, which cannot be captured easily using the SES approach. With regard to the British context, some minority ethnic groups are more religious than Whites but have lower socioeconomic positions. For instance, people of Pakistani/Bangladeshi origins who are mostly Muslim are the poorest group, with 57 and 49 per cent in poverty as compared with 18 per cent at the national level (Heath and Li, 2014), and are most likely to be in the lowest social class. How class, income, ethno-religious identity and demographic factors such as health and marital status impact on formal and informal social involvement and on philanthropic giving is the question we try to address in the following analysis, paying special attention to the interplay between class and income. As both absolute and relative giving among givers (also called 'donors' or 'contributors' in the literature, and the terms will be used interchangeably in the following analysis) and among all respondents (including non-givers) is important in the analysis of philanthropic behaviour, we shall take all these factors into account.

\section{DATA}

We use the Home Office Citizenship Survey (HOCS 2001-11) for the analysis (available at http://discover.ukdataservice.ac.uk/series/?sn=200007). The HOCS is the flagship survey on community cohesion for adults aged 16 or over and resident in England and Wales. The data available at the time of analysis for the present study cover a period of ten years from 2001 to 2011. The survey commenced on a biennial basis in 2001 and moved to a continuous design in April 2007, whereby the data for four quarters are aggregated into yearly datasets. Altogether seven datasets are available (2001, 2003, 2005, 2007/8, 2008/9, 2009/10, 2010/11).

\section{File supplied to Li - Not for distribution}


Each of the HOCS datasets has around 14000 to 16000 respondents, with a core sample of around 10000 as representative of the general population and a boost sample of around 5000 from minority ethnic groups (including around 1000 Muslims). The HOCS adopts a multi-stage stratified random sampling procedure with face-to-face interviews. The overall response rates are around 63-67 per cent each year. Four sets of weights are provided by the data collectors to allow analysis using both core and combined (core plus boost) samples and at both individual and household levels. For consistency, we use the individual weights for the combined samples in all datasets as this is the most suitable for our analysis. The data contain information on formal and informal social involvement, charitable giving and a whole range of socio-demographic attributes including class, income and cultural (ethno-religious) identity, all using standard classifications in government and academic surveys (Attwood et al., 2003).

As our outcomes of interest in this analysis pertain to joining (volunteering in civic activities), helping (informal support to non-kin others living outside one's household), and giving (to charitable causes), we follow the standard practice (DCLG, 2010a, 2010b) in calculating the incidences of the three domains of pro-social behaviour. In addition, we differentiate between absolute and relative giving, both by donors and for all respondents in different social groups, such as by donors in working-class and donors in salariat positions, and for all respondents in working-class and salariat positions, that is, including non-givers. This is crucial in analysis of civic behaviour, as Schervish and Havens (1995) emphasized, although existing studies tend to focus on one or another of these aspects (Brooks, 2005; Brown and Ferris, 2007). Absolute giving refers to the amount that our respondents reported that they had given to charitable causes in the month previous to the interview, and relative giving to the amount as a fraction of their own (or if partnered, the average of the couple's) incomes. ${ }^{2}$ The income data in the HOCS were recorded in bands and we used the mid-points in the calculation. As the data on the amounts given started in 2003, both income and giving data are GDP-deflated to the 2003 price (http://www.hm-treasury.gov.uk/data_gdp_fig.htm). The causal relationship among joining, helping and giving is difficult to establish using cross-sectional data, but we are aided in the present case by the different time orders among the three variables. Thus, our joining and helping indicators relate to the last twelve months and our giving data to the last four weeks, which gives some temporal priority of joining and helping over giving. (One might, of course, argue that the pro-social propensity is a stable attribute of givers and as such it may have helped them to join in civic activities and help others prior to their giving activity.) For space reasons, we do not repeat the lengthy questions on joining, helping and giving here, which are all available via the link noted above. For explanatory variables, we use class, income, ethno-religious identity and demographic attributes such as age, sex, marital status and nativity.

\section{ANALYSIS}

We start with the overall trends in the three domains of generosity: joining, helping and giving in England and Wales (2001-11). Figure 3.1 shows the percentages (the three lines at the top) of the respondents who reported having volunteered in civic activities and given unpaid help to non-kin over the previous year, and made donations to charitable

\section{File supplied to Li - Not for distribution}




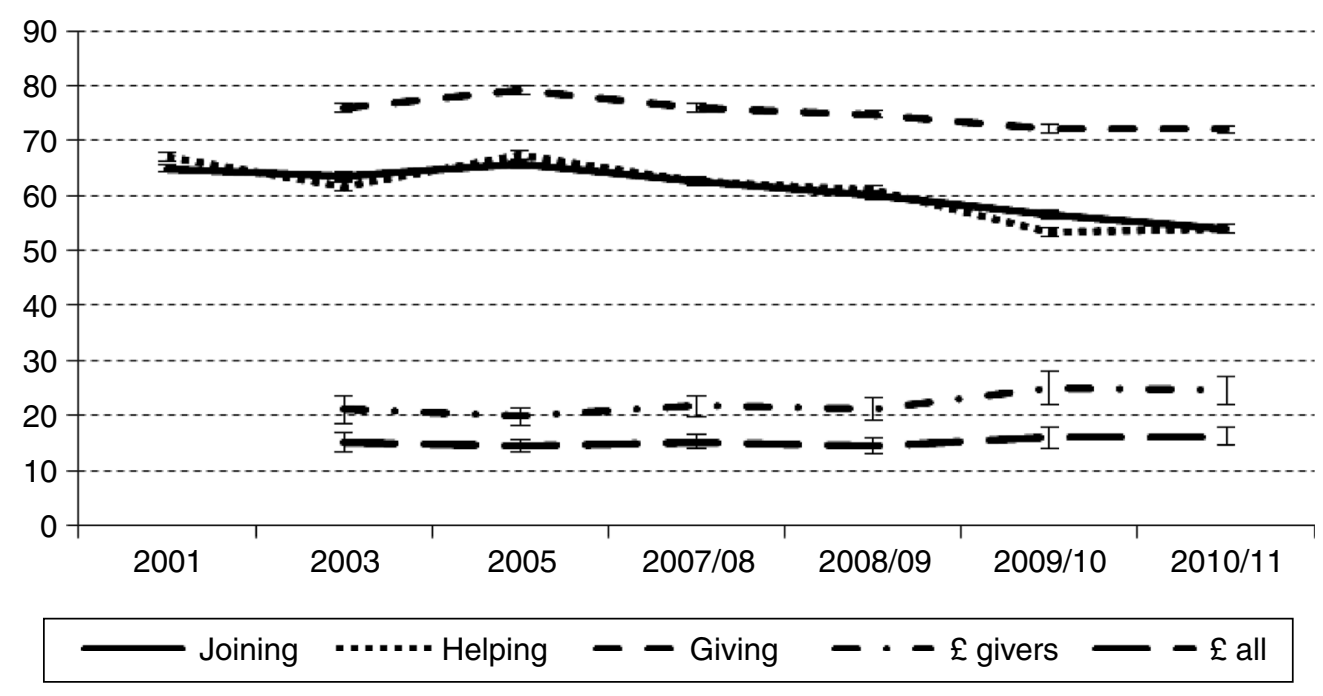

Note: The figures refer to the percentages of respondents who report that they joined or helped in the last 12 months or gave to charitable causes in the last four weeks, and to the amounts given to charitable causes. The amounts are GDP-deflated (in 2003 prices).

Source: The Home Office Citizenship Survey (2001-2011).

Figure 3.1 Formal volunteering, informal helping and charitable giving

causes over the previous month, as well as the amounts (in sterling pounds) given by contributors and by all respondents (the two lower lines). We have also included the 95 per cent confidence intervals for the data points which, as argued by McKenzie (2012), are crucial for detecting possible changes at the population level. The data show that people in England and Wales are, overall, quite generous. About 55-80 per cent joined in civic activities, gave informal help to non-kin others and gave to charitable causes. It is also clear that the three lines were fairly stable up to 2005 but then started to decline, by around 10-15 percentage points by the end of the period covered. A potential cause of the decline in the three rates is the economic recession that started in 2008 with much media coverage about the imminent onset of economic hardship, rising unemployment, benefit cuts and social unrest. In the context of perceived or experienced economic hardships, more people have started to withdraw from formal and informal social involvement and charitable giving. Yet, while the rates of joining, helping and giving were falling, the amounts given both by contributors and among all respondents were fairly stable, at around $£ 20$ by contributors and $£ 15$ among all respondents in each year, with an apparent (though non-significant) increase in both respects. ${ }^{3}$ The consistency in the patterns gives us considerable reassurance about the data quality.

Having looked at the overall trends, we proceed to the socioeconomic and cultural influences on the incidences of joining, helping and giving in terms of class, income, ethnicity and religion. With regard to class, we use the NSSeC schema with (1) higher (professional-managerial) salariat; (2) lower salariat; (3) intermediate (routine

\section{File supplied to Li - Not for distribution}



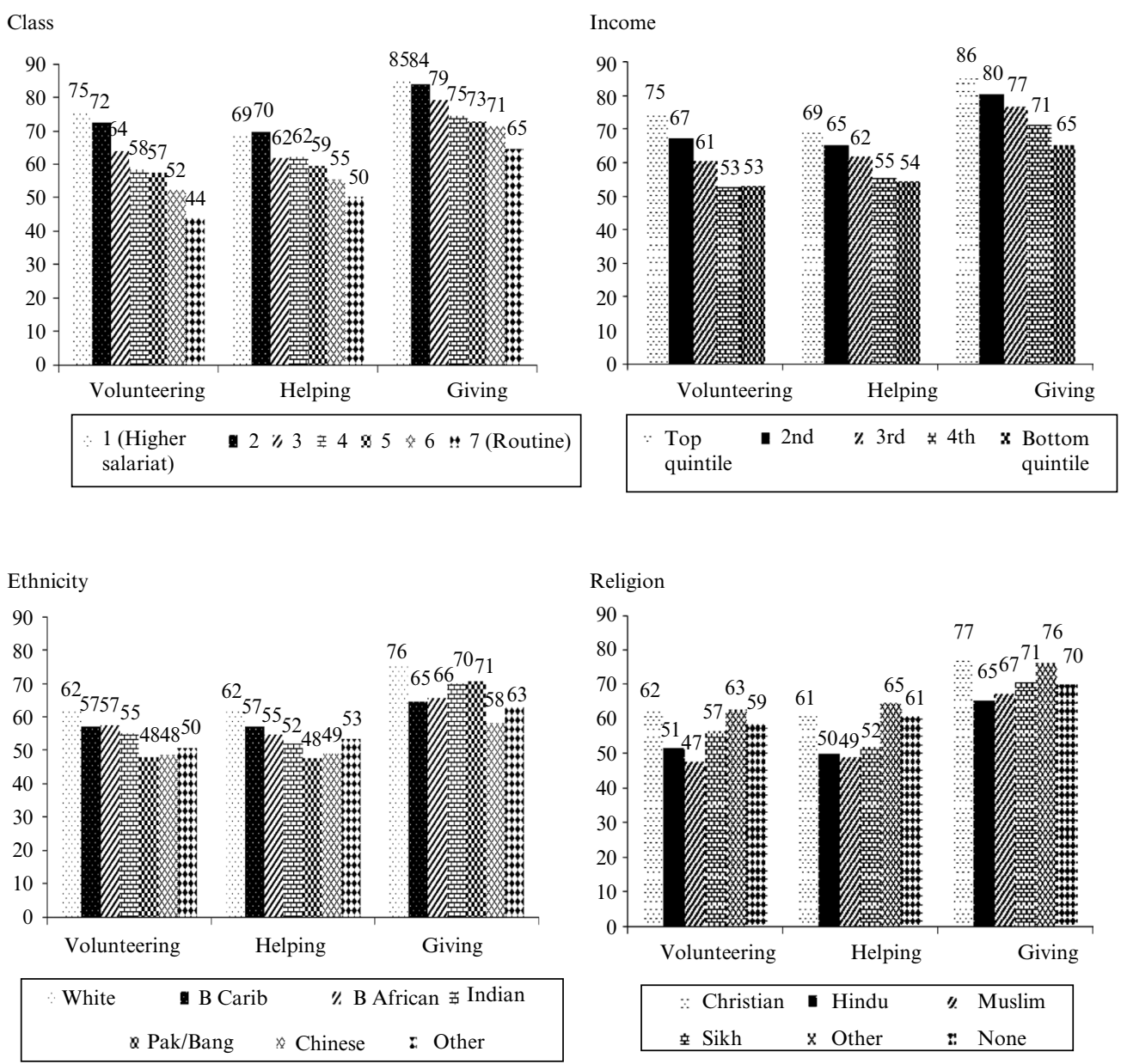

Source: The Home Office Citizenship Survey (2001-2011).

Figure 3.2 Class, income and ethno-religious differences in volunteering, helping and giving $(\%)$

non-manual and clerical); (4) own-account (self-employed with or without employees); (5) manual supervisor and technician; (6) semi-routine; and (7) routine workers. The income data are coded in quintiles. For ethno-religious identity, we differentiate White, Black Caribbean, Black African, Indian, Pakistani/Bangladeshi, Chinese and Other (for ethnicity); and Christian, Hindu, Muslim, Sikh, Other and None (for religion).

The data in Figure 3.2 show strong class and income but weak ethno-religious effects. The class and income effects are more salient on joining and giving, and less so on helping, suggesting that joining and giving require considerably more socioeconomic resources than helping. The ethno-religious effects have no clear patterns, although Whites and Christians were a bit more likely to join in civic activity, help non-kin, and give to charity 
than the other groups. It is also interesting to note that people of Pakistani/Bangladeshi heritages (96 per cent of them are Muslims) and Muslims (19 per cent of Black Africans and 14 per cent of Indians are also Muslims) are less likely to join or help but more likely to give than other ethno-religious groups. As the data do not contain information on the specific causes of donation, we could only conjecture that our Muslim respondents were more likely to give for religious purposes.

Looking more closely at the class differences, we find a generally smooth gradient in the likelihood of joining and giving. The differences between the higher salariat and the routine manual workers are most clearly shown in joining, with a difference of 31 percentage points ( 75 versus 44 per cent for the two classes respectively), less so in giving and helping but still salient, with a difference of around 20 percentage points respectively. Income exhibits a weaker effect, with those in the top quintile being most likely to give their time, attention and money to community affairs, people in need or charitable causes $(75,69$ and 86 per cent in joining, helping and giving), in chief contrast to those in the bottom quintile (53,54 and 65 per cent respectively).

One might expect ethnic differences in civic engagement to exhibit themselves mainly between Whites and non-Whites and not so much among the minority ethnics, on the grounds that the latter are less familiar with civic organizations in Britain. This is, however, not supported in the data. Whites are, on the whole, more likely (at 62 per cent) to join in civic activities than minority ethnics, but the two Black groups and Indians are close behind, at 55-57 per cent. Pakistani/Bangladeshi and Chinese civic involvement is markedly lower, at 48 per cent. The pattern on informal help is very similar to that on civic engagement, with Pakistanis/Bangladeshis being the least likely to help non-kin, which may be due to their greater caring needs within their household they tend to have large family sizes embedded in multi-generational households and have poor health (Heath and Dale, 1994), or to a cultural difference in the perception of help - they tend to live in closely knit communities where exchanges of favour may not be regarded as 'help'.

Turning to religious effects, we find no clear distinction between religious affiliation and the propensity to give, nor is there such a relationship on civic participation and informal help, which is quite different from findings in the US research (Regnerus et al., 1999; Putnam, 2000; Putnam and Campbell, 2010). While Christians and the 'Other' group comprising mainly Jews and Buddhists are somewhat more likely to show prosocial behaviour, people with no religious affiliations ('None') are found to be more likely to volunteer in formal civic activities, provide informal help, and give money to charitable causes than Hindus, Sikhs or Muslims (the difference in giving is negligible between Muslims and the atheists, though). ${ }^{4}$ Therefore our prima facie evidence does not support Putnam's argument about the relationship between religious networks and philanthropic behaviour. It is here acknowledged, though, that as our indicator of religion is religious affiliation rather than religiosity, the analysis in this regard is not a direct test of his hypothesis.

Having looked at the broad profiles of the three domains of generosity, we now come to a closer look at absolute and relative giving. We do this both for donors and for all respondents (including non-givers) in terms of class, income and ethno-religious identity. The data are shown in Figure 3.3. The primary axis refers to absolute, and the secondary axis, relative giving. Our purpose here is to see whether British giving is similar to

\section{File supplied to Li - Not for distribution}



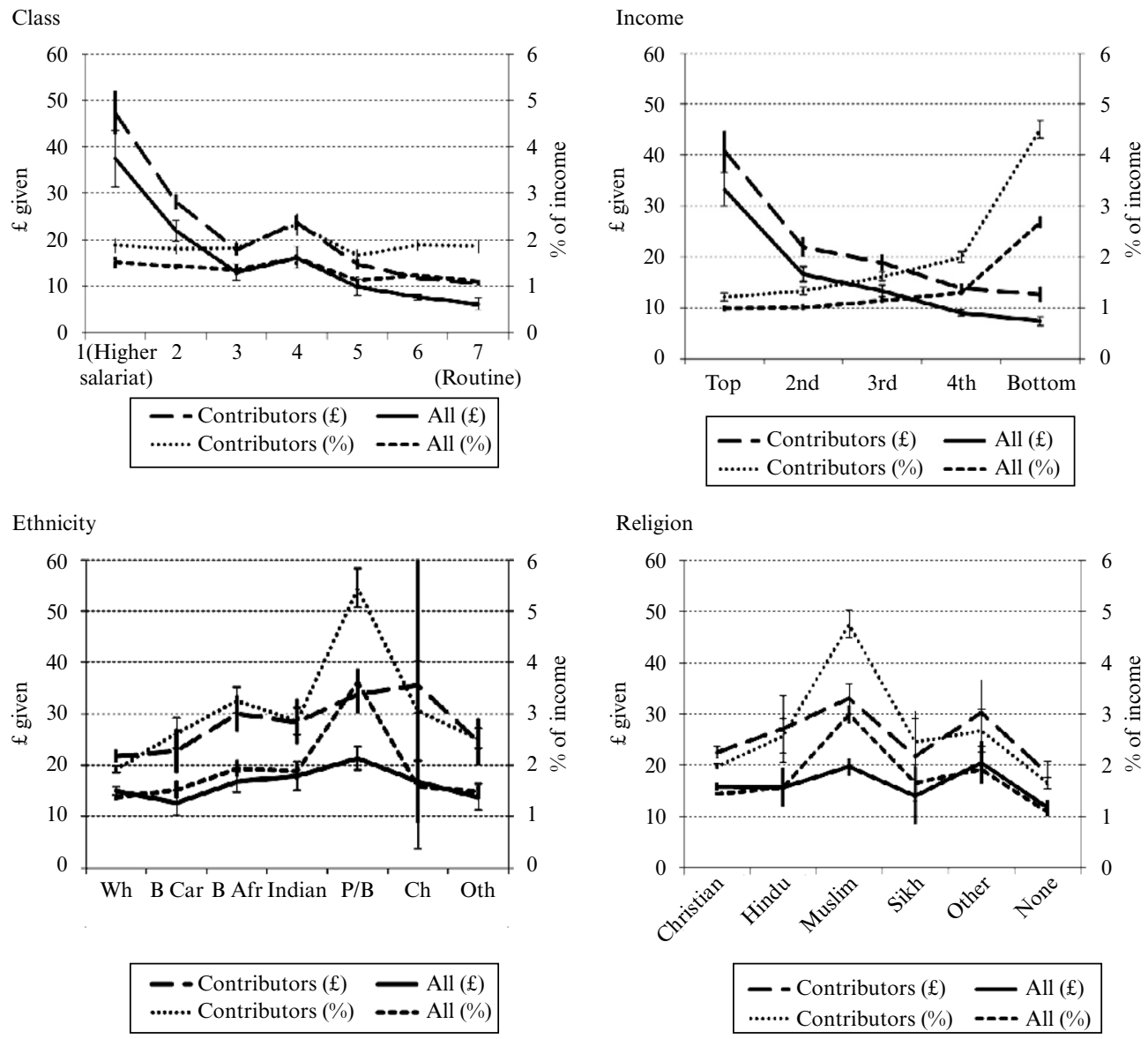

Source: The Home Office Citizenship Survey (2001-2011).

Figure 3.3 Class, income and ethno-religious differences in absolute and relative giving

or different from US giving as discussed above, namely, whether there is a 'flat-line', 'U-shape' or inverse class-giving profile.

The evidence in Figure 3.3 shows little support to the three theses on US giving. First, with regard to class giving, we do not find that people in higher class positions give less than those in lower class positions, in terms of either absolute or relative giving, and with or without the inclusion of non-givers. When we include non-givers ('All (\%)' in the figure), people in higher class positions actually give significantly more in relative terms than those in lower classes. We also find that people in Class 4, namely, the self-employed, give significantly higher proportions of their incomes than people in most other classes. This remains essentially the same whether we include or exclude non-givers. The distinctiveness of this pattern would not have been available if one had used a continuous measure for class. Secondly, with regard to the 'flat-line' and 'U-shape' theses that refer

\section{File supplied to Li - Not for distribution}


to income rather than class, we find no evidence, in either absolute or relative giving, and for either givers or including non-givers, of flat-line or U-shape giving. People in higher income brackets tend to give more in absolute terms, just like those in higher class positions, but people with lower incomes tend to give more in relative terms. The pattern here is rather different from that as depicted in Schervish and Havens (1995: 89, Figure 3), or James and Sharpe (2007: 230, Figure 3). ${ }^{5}$

Also included in Figure 3.3 are patterns of ethno-religious giving. Here we find that Muslims and people of Pakistani/Bangladeshi origins tend to give more in absolute terms than most other groups and give the most in relative terms. Nearly all those of Pakistani and Bangladeshi origins are Muslims (96 per cent) although they only comprise slightly over half (56 per cent) of the Muslim population in Britain. Among the Muslims, Pakistani/Bangladeshi and Indian contributors gave much more than their White peers ( $34, £ 40$ and $£ 24$ respectively). Because of their low incomes, Pakistani/Bangladeshi Muslim contributors gave the highest proportions of their incomes (6.29 per cent), as compared with the 5.63, 3.72 and 2.53 per cent among Indian, Black African and White Muslim contributors. South Asian Muslims thus gave more than other Muslims in relative terms. People without religious affiliation tend to give less in both absolute and relative terms than those with religious affiliations. Combining the patterns here and those in Figure 3.2, we can say that Putnam's notion of religious network effects gets some qualified support in the British context, namely, that while religion does not enhance people's propensity to give, it does prompt people with religious affiliations to give more than those with no religion.

Having looked at the overall trends as well as the class, income, and ethno-religious effects on joining, helping and giving, we now explore how the three domains impact on one another, and how socioeconomic-cultural and other demographic attributes jointly affect people's generosity. We do this in two steps. First, we model the three incidences of generosity (joining, giving and helping) using logit regressions. Secondly, we model the absolute and relative giving among givers and for all respondents. For absolute giving, we use ordinary least squares (OLS) regression. For relative giving, we use generalized linear modelling (GLM), which constrains the expected outcomes to be within the percentage range. The logit coefficients are shown in Table 3.1, and the OLS and GLM coefficients in Table 3.2.

The data in Table 3.1 show that the three domains have mutually reinforcing effects even when the impacts of a large number of socio-demographic factors are taken into account. Thus joiners are more likely to be helpers than non-joiners, helpers more likely to be joiners, and both joiners and helpers more likely to give than those with neither formal nor informal social involvement. Class and income have marked effects, whereas cultural (ethno-religious) and demographic attributes have rather limited impacts. Class effects are most salient in joining and have a smooth gradient, with the higher salariat being nearly three times (in terms of odds) as likely to join civic organizations as the routine working class $\left(\mathrm{e}^{0.987}=2.68\right)$. The class effects on giving are also marked, with the higher salariat being nearly twice as likely to donate to charitable causes as the routine working class $\left(\mathrm{e}^{0.623}=1.86\right)$. With regard to helping, class effects are weaker than in joining or giving but are still notable. In fact, they are more salient than those associated with income or other cultural-demographic attributes although here we find that it is the lower salariat who are the most helpful, being 59 per cent more likely to

\section{File supplied to Li - Not for distribution}


50 Handbook of research methods and applications in social capital

Table 3.1 Logit regression coefficients on joining, helping and giving

\begin{tabular}{|c|c|c|c|}
\hline & Joining & Helping & Giving \\
\hline Joining & - & $0.817 * * *$ & $0.653^{* * *}$ \\
\hline Helping & $0.817 * * *$ & - & $0.697 * * *$ \\
\hline Giving & $0.651 * * *$ & $0.694 * * *$ & - \\
\hline \multicolumn{4}{|l|}{ Class (routine $=$ ref.) } \\
\hline Higher salariat & $0.987 * * *$ & $0.388^{* * *}$ & $0.623^{* * *}$ \\
\hline Lower salariat & $0.885^{* * *}$ & $0.465^{* * *}$ & $0.544 * * *$ \\
\hline Intermediate & $0.644 * * *$ & $0.141 * * *$ & $0.348 * * *$ \\
\hline Own account & $0.439 * * *$ & $0.368 * * *$ & $0.229 * * *$ \\
\hline Supervisor/Technician & $0.423 * * *$ & $0.224 * * *$ & $0.215^{* * *}$ \\
\hline Semi-routine & $0.271 * * *$ & 0.041 & $0.173 * * *$ \\
\hline \multicolumn{4}{|c|}{ Income quintiles (bottom $=$ ref.) } \\
\hline Top & $0.442 * * *$ & 0.017 & $0.587 * * *$ \\
\hline 2 nd & $0.296 * * *$ & 0.024 & $0.378 * * *$ \\
\hline $3 \mathrm{rd}$ & $0.171 * * *$ & 0.036 & $0.310 * * *$ \\
\hline 4 th & 0.040 & 0.014 & $0.148 * * *$ \\
\hline \multicolumn{4}{|l|}{ Ethnicity (White = ref.) } \\
\hline Black Caribbean & 0.024 & 0.014 & $-0.282 * *$ \\
\hline Black African & 0.054 & $-0.181^{*}$ & -0.050 \\
\hline Indian & -0.017 & -0.161 & 0.181 \\
\hline Pakistani/Bangladeshi & -0.119 & $-0.355^{* *}$ & $0.356^{* *}$ \\
\hline Chinese & -0.297 & $-0.367^{*}$ & -0.175 \\
\hline Other & $-0.168^{*}$ & -0.126 & -0.139 \\
\hline \multicolumn{4}{|l|}{ Religion (None $=$ ref.) } \\
\hline Christian & $0.257 * * *$ & 0.020 & $0.190 * * *$ \\
\hline Hindu & -0.108 & -0.142 & 0.001 \\
\hline Muslim & -0.026 & 0.043 & $0.282 * *$ \\
\hline Sikh & 0.159 & -0.100 & 0.146 \\
\hline Other & $0.351 * * *$ & $0.187 * * *$ & $0.301 * * *$ \\
\hline Female & -0.025 & $0.175^{* * *}$ & $0.439 * * *$ \\
\hline Having long-term illness & 0.014 & 0.037 & $-0.054 *$ \\
\hline Non-partnered & $-0.090^{* * *}$ & 0.018 & $-0.053^{*}$ \\
\hline Age/10 & $-0.092 * * *$ & 0.036 & $0.189 * * *$ \\
\hline Age/10 squared & 0.005 & $-0.016^{* * *}$ & $-0.015 * * *$ \\
\hline Foreign born & $-0.190 * * *$ & $-0.138 * * *$ & $-0.324 * * *$ \\
\hline No. of dependent children & $0.133^{* * *}$ & $0.040 * * *$ & 0.021 \\
\hline \multicolumn{4}{|l|}{ Year $(2010 / 11=$ ref. $)$} \\
\hline 2003 & $0.327 * * *$ & $0.188^{* * *}$ & 0.036 \\
\hline 2005 & $0.411 * * *$ & $0.444 * * *$ & $0.212 * * *$ \\
\hline 2007 & $0.297 * * *$ & $0.241 * * *$ & 0.056 \\
\hline $2008 / 09$ & $0.175^{* * *}$ & $0.200^{* * *}$ & -0.004 \\
\hline $2009 / 10$ & $0.144 * * *$ & $-0.093 * * *$ & 0.029 \\
\hline Constant & $-1.306^{* * *}$ & $-0.825^{* * *}$ & $-0.986 * * *$ \\
\hline Pseudo $\mathrm{R}^{2}$ & 0.100 & 0.081 & 0.087 \\
\hline $\mathrm{N}$ & 72936 & 72936 & 72936 \\
\hline
\end{tabular}


Table 3.2 OLS coefficients on absolute giving and GLM coefficients on relative giving

\begin{tabular}{|c|c|c|c|c|}
\hline & \multicolumn{2}{|c|}{ Absolute giving $(£)$} & \multicolumn{2}{|c|}{ Relative giving (as $\%$ of income) } \\
\hline & Contributors & All & Contributors & All \\
\hline Joining & $6.58 * * *$ & $6.78^{* * *}$ & $0.38 * * *$ & $0.56^{* * *}$ \\
\hline Helping & 1.46 & $3.18 * * *$ & 0.13 & $0.31 * * *$ \\
\hline \multicolumn{5}{|l|}{ Class (routine $=$ ref.) } \\
\hline Higher salariat & $25.40 * * *$ & $21.13 * * *$ & $0.65^{* * *}$ & $0.80^{* * * *}$ \\
\hline Lower salariat & $11.12 * * *$ & $9.06^{* * *}$ & $0.44 * * *$ & $0.59 * * *$ \\
\hline Intermediate & $4.78^{*}$ & $3.74 *$ & 0.24 & $0.36^{* *}$ \\
\hline Own account & $6.85^{* *}$ & $4.57^{*}$ & $0.46^{* *}$ & $0.55^{* * *}$ \\
\hline Supervisor/Technician & 1.08 & 0.70 & 0.09 & 0.18 \\
\hline Semi-routine & 1.11 & 0.82 & 0.04 & 0.12 \\
\hline \multicolumn{5}{|l|}{ Income (bottom = ref.) } \\
\hline Top & $14.85^{* * *}$ & $14.27^{* * *}$ & $-1.85^{* * *}$ & $-1.68 * * *$ \\
\hline 2nd & 1.02 & 2.08 & $-1.58 * * *$ & $-1.45^{* * *}$ \\
\hline $3 r d$ & -0.14 & 0.80 & $-1.28 * * *$ & $-1.17 * * *$ \\
\hline 4th & -3.15 & -1.58 & $-0.95 * * *$ & $-0.88 * * *$ \\
\hline \multicolumn{5}{|l|}{ Ethnicity (White = ref.) } \\
\hline Black Caribbean & 5.30 & 2.05 & 0.23 & 0.13 \\
\hline Black African & 12.73 & 7.00 & 0.42 & 0.33 \\
\hline Indian & 10.74 & 7.88 & 0.28 & 0.35 \\
\hline Pakistani/Bangladeshi & 10.14 & 8.66 & 0.42 & 0.54 \\
\hline Chinese & 26.35 & 12.51 & 0.41 & 0.25 \\
\hline Other & 7.17 & 3.80 & 0.10 & 0.04 \\
\hline \multicolumn{5}{|l|}{ Religion (None = ref.) } \\
\hline Christian & 2.42 & $2.67^{*}$ & 0.11 & 0.16 \\
\hline Hindu & -1.36 & -1.39 & -0.02 & -0.06 \\
\hline Muslim & $15.45^{*}$ & $11.17^{*}$ & 0.38 & 0.40 \\
\hline Sikh & -4.77 & -2.62 & -0.29 & -0.28 \\
\hline Other & $8.44 *$ & $7.12 * *$ & $0.39^{*}$ & $0.45^{*}$ \\
\hline Female & $-5.07 * * *$ & $-2.39 * *$ & -0.04 & 0.06 \\
\hline Having long-term illness & -0.90 & -0.81 & 0.04 & 0.03 \\
\hline Non-partnered & -0.84 & -0.67 & $-0.51 * * *$ & $-0.52 * * *$ \\
\hline Age/10 & 2.32 & 2.14 & -0.07 & -0.04 \\
\hline Age/10 squared & -0.02 & -0.06 & 0.01 & 0.01 \\
\hline Foreign born & -2.05 & -2.39 & 0.04 & -0.04 \\
\hline No. of dependent children & 0.84 & 0.78 & 0.02 & 0.02 \\
\hline \multicolumn{5}{|l|}{ Year $(2010 / 11=$ ref.) } \\
\hline 2003 & -3.12 & -2.01 & -0.18 & -0.17 \\
\hline 2005 & $-5.01 * *$ & $-3.10^{*}$ & $-0.22^{*}$ & -0.17 \\
\hline 2007 & -3.27 & -2.17 & -0.14 & -0.12 \\
\hline 2008/09 & $-4.17 *$ & $-2.86^{*}$ & -0.16 & -0.17 \\
\hline $2009 / 10$ & 0.55 & 0.34 & -0.06 & -0.08 \\
\hline Constant & -1.01 & -6.76 & $-3.23 * * *$ & $-4.18 * * *$ \\
\hline Adj. R²/BIC & 0.02 & 0.01 & -500111.6 & -746793.3 \\
\hline $\mathrm{N}$ & 52384 & 72935 & 46746 & 67448 \\
\hline
\end{tabular}


help than the routine working class. ${ }^{6}$ People in Class 2 (lower salariat) tend to be school teachers, nurses, social workers and lower-grade administrators, whose job is mainly to help people rather than work with machines or perform clerical duties. Therefore the Class 2 effect is not merely a gender effect as gender is controlled for in the model. People in Class 4 (own-account workers), such as shop-keepers, plumbers, small employers, are also highly helpful $\left(\mathrm{e}^{0.368}=1.44\right)$. Their daily jobs involve much personal contact with others, especially those in local areas. Helping others and having good relations with people in the local community may also help themselves in bringing more business opportunities. Indeed one might say that offering help is part and parcel of Class 2 people's professional work, and having good relations with the local community is a precondition of a small businessperson's success. This, of course, does not mean that people in working-class positions are uncaring or ungenerous, as research (Li et al., 2005) shows them to have very strong neighbourhood attachment, but it suggests that those in higher class positions have more socio-cultural-economic resources and opportunities which make it easier for them to undertake formal and informal social activities and to give to charitable causes.

The income effects are much weaker than class effects on joining and helping but they are on a par in giving. Income effects are strongest in giving, weaker in joining, and negligible in helping. Ethnicity plays a rather limited role in all three domains. We noted earlier that Pakistanis/Bangladeshis are less likely to join or help but more likely to give than some other minority ethnic groups and this is still shown here when the effects of the other factors in the model are taken into account. The effects of religious identity are also weak, unlike the powerful effects of 'American Grace' as depicted in Putnam and Campbell (2010). Christians, though, do show themselves as distinctive joiners and givers, as do Muslims as givers.

The demographic effects are as usually found in the social capital literature. For instance, women are more likely to volunteer and to give than men. The partnered are more likely to join (such as PTA) and to give. Older people are more likely to give, echoing Smith (2012: Figure 5) in this regard, and less likely to join than young people. Those born outside the UK tend to score low in all three domains. The number of dependent children is, other things being equal, positively associated with generous behaviour, possibly because parents wish to set themselves as role models for their children. With regard to trends, we find a significant decline in all three respects over the time period covered.

Having looked at the incidences in the three domains of generosity, we proceed to absolute and relative giving. The data are as shown in Table 3.2 using OLS and GLM models and with the same explanatory variables as in Table $3.1 .^{7}$ For both absolute and relative giving, we conduct analyses for givers only, and for all respondents, that is, including non-givers (called 'Contributors' and 'All' in the table). With regard to absolute giving under columns 2 and 3 of the table, we see that, other things being equal, joiners give significantly more than non-joiners, but helpers do not give more among contributors. The patterns here echo Putnam's findings in the US (Putnam, 2000: 121). The class effects are pronounced, more so among contributors than among all, with the higher salariat giving $£ 25$ more among contributors and $£ 21$ more among all than their working-class peers. People in the top quintile of income also give more, by around $£ 15$, but there are no significant differences among those in the lower income bands. Other

\section{File supplied to Li - Not for distribution}


things being equal, the cultural effects are less marked, with the exception of Muslims and Christians. The findings here reinforce those we found in Figure 3.3 and add a further feature, namely, that in terms of net impacts, there are notable (and significant) religion but little ethnicity effects. For instance, people of Pakistani/Bangladeshi and Black African origins tend to give more, but not significantly so if they are not Muslims; yet Muslims tend to give significantly more, regardless of ethnicity.

Turning to data on relative giving as shown in the last two columns of Table 3.2, we find features that are in some aspects similar to, but in others different from, those on absolute giving. The direction of joining and helping effects are similar. The class effects among all respondents are stronger than those among donors only, for every class category, which is different from the pattern in absolute giving. ${ }^{8}$ We also find that, other things being equal, income is strongly but negatively associated with relative giving: the more money one has, the smaller proportion one gives. Here we find that the income effects are stronger for contributors than among all respondents, which applies at every level of income. Further analysis confirms that the differences at every band $(0.17,0.13$, 0.10 and 0.07 percentage points from the top to the fourth quintiles) are statistically significant at the 0.001 level. It is also noted here that while the data in Figure 3.3 showed an increasing divergence from higher to lower bands between donors and all respondents in relative giving, the results here suggest that, in terms of net effects, there were actually greater differences among people in the higher than in the lower income bands. Finally in this context, we note that in sharp contrast to the strong class and income effects, there are, other things being equal, no significant ethnic or religious or demographic effects except that the non-partnered tend to give less, and this holds true for contributors as for all respondents.

The findings of positive class but negative income effects on relative giving indicate interaction effects between class and income. People in higher class positions tend to have higher incomes than those in lower class positions. In our data, 53.6 per cent of Class 1 respondents are in the top quintile and only 2.9 per cent are in the bottom quintile. On the other hand, only 3.4 per cent of the routine workers are in the top quintile and 34 per cent are in the bottom quintile. Given the general importance attached to relative giving in the literature and the patterns of class and income effects in the analyses above, we present further evidence on the interplay between class and income on relative giving, holding the covariates in the models at their means.

Figure 3.4 shows the net class and income interaction effects in relative giving, for contributing and among all respondents respectively. The top panels show the class and income effects, whilst the bottom panels focus on some contrast groups in the trends where we highlight the giving profile by some class-income groupings that merit special attention: people in Classes 1, 4 and 7 in the top and the bottom quintiles of income from 2003 to 2011. With regard first to class and income effects among givers, we find that even though there are class effects among those in the top quintile, the differences are relatively small, at 0.77 percentage point between Classes 1 and 7, giving 1.48 and 0.71 per cent respectively of their incomes, netting out all other cultural-demographic differences. Yet the lower the income bands, the larger the class differences. For contributors in the bottom quintile of income, the class differences increased to 4.15 percentage points: 7.44 per cent for Class 1 and 3.29 per cent for Class 7 in the net effects. The pattern for all respondents (including non-givers) is similar to that for donors only,

\section{File supplied to Li - Not for distribution}




\section{Handbook of research methods and applications in social capital}
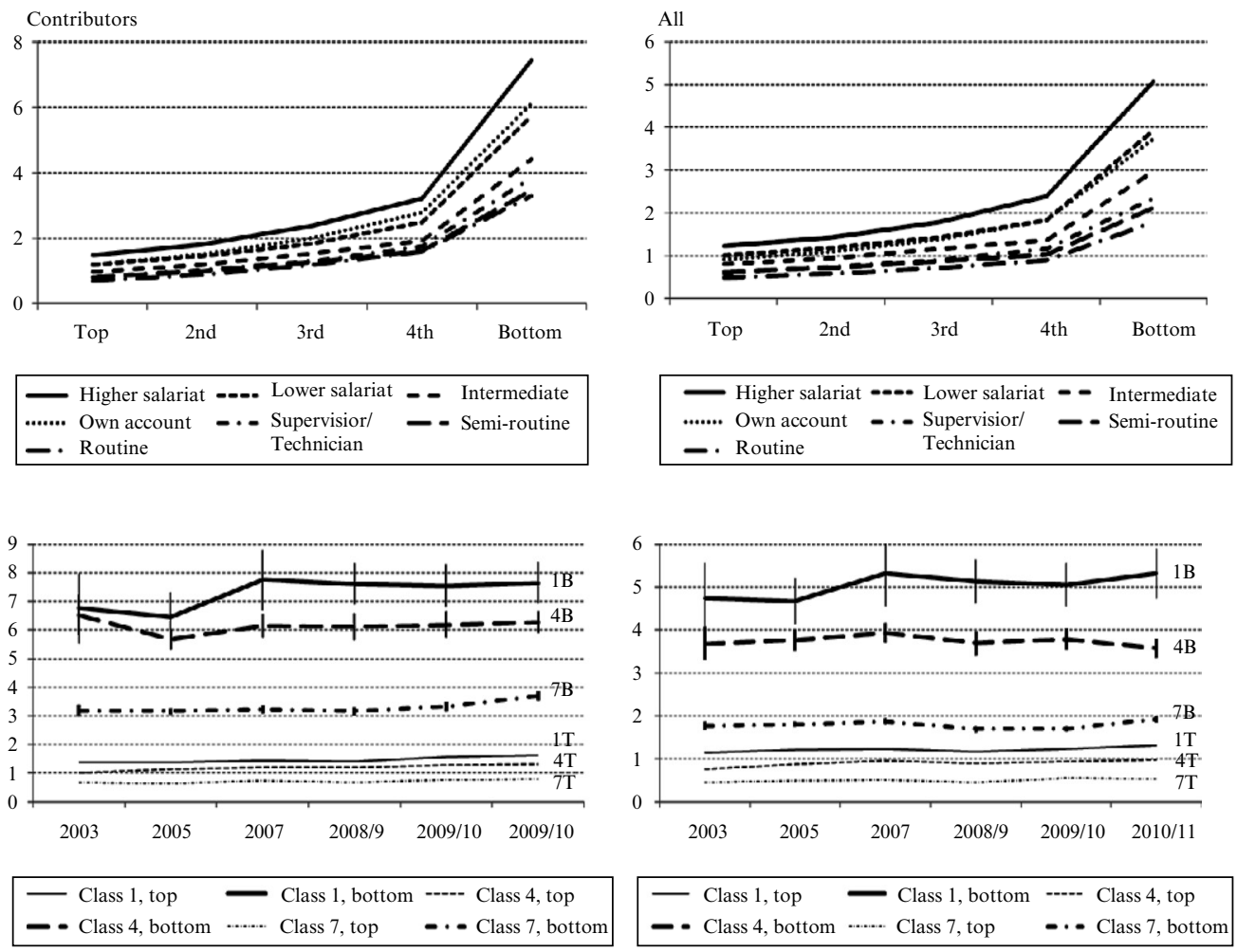

Note: Different scales are used in the panels.

Source: The Home Office Citizenship Survey (2001-2011).

Figure 3.4 Class and income effects in relative giving

although the effects are smaller, with a 0.72-point difference between Classes 1 and 7 (at 1.22 and 0.50 per cent respectively) in the top quintile, and a 3.28-point difference in the bottom quintile (at 5.07 and 1.79 per cent respectively). Thus, the poor tend to give more than the rich, and people in higher class but lower income positions tend to give the most.

We now turn to trends of relative giving in the selected class-income combinations (Classes 1, 4 and 7 in the top and the bottom quintiles, called 1T, 4T, 7T, 1B, 4B and 7B respectively) for 2003-11, as shown in the lower panels of Figure 3.4. (We show the 95 per cent confidence intervals for the three groups in the bottom income bands, not those in the top bands, as the differences among them are negligible.) Among givers, we find that the higher salariat in the bottom income band (1B) are the most generous and, at least on the face of it, increasingly so from 2007 onwards as compared with 2003 and 2005 (the 95 per cent confidence intervals showed the increases as non-significant, though). The second most generous group are the self-employed in the lowest income band (4B), followed by the routine workers in the lowest income band (7B). The most privileged, namely those in the top income band and in higher salariat positions (1T),

\section{File supplied to Li - Not for distribution}


only give around one fifth as much as their financially poor class peers (1B), and only around half a percentage point more than their income peers in routine manual class positions (7T). ${ }^{9}$ The patterns for all respondents (that is, including non-givers) are similar, albeit at a lower level. The most privileged (Class 1 in the top income band, 1T) are behind the most disadvantaged (Class 7 in the bottom income band, 7B) by around 0.5 percentage point in relative giving in each of the years. Therefore, whether we confine the analysis to givers or extend it by including non-givers, the basic picture is the same: the most privileged gave less than the least privileged: about half among givers and roughly two-thirds including non-givers.

\section{CONCLUSION}

In this study, we analysed three domains of generosity in England and Wales - joining, helping and giving - over the ten-year period 2001-11. With regard to the last domain, we differentiated between absolute and relative giving, and analysed them for givers and among all respondents (including non-givers) within the class, income and ethnoreligious categories. The HOCS data we used contain the most authoritative information currently available, including a whole range of socioeconomic-cultural and demographic factors that allow us to examine their impacts on the three domains of generosity. While our research was mainly aimed at depicting the patterns and trends, the interrelationships and the socioeconomic-cultural underpinnings of the three domains of generosity in England and Wales, it was also, at least partially, aimed at finding out whether the British evidence was similar to or different from the main theses arising from US research.

Our main findings can be summarized as follows. First, at the most general level, we found that people in England and Wales are quite generous in giving their time, effort and money, with over 70 per cent being donors and over 60 per cent being joiners and helpers. The recession, though, seemed to be taking a toll in all three respects, with falling rates in joining and helping. Yet although the proportion of people who gave money declined, the amounts given stayed at a fairly similar level, whether we look at the amounts by givers or including non-givers in the calculation. It thus seems that even though economic hardships, experienced or anticipated, were turning some people away from altruistic behaviour, there was a core (over half of the adult population) who were little affected by the macroeconomic milieu or, one might even say that the recession made them even more determined to help by giving more than in previous years to charitable causes.

Secondly, in line with previous research on social capital in Britain ( $\mathrm{Li}, 2010)$, we found mutually reinforcing effects between formal and informal social engagement and, additionally as emerged in this study, a positive impact of both on giving, in terms both of the propensity to give and of the absolute and the relative amounts that were given (and in the latter regard, both among givers and including non-givers). Furthermore, we found a strong socioeconomic but a weak cultural (ethno-religious) basis in all three domains of generosity. Our evidence gives little support to the three theses on giving in the US literature: the flat-line, U-shape, and negative class effects, although we did find some support for Putnam's argument about the religious network effects on giving. The

\section{File supplied to Li - Not for distribution}


differences between our findings and those in the US studies may reflect methodological differences (the US studies used fewer controls), differences in the socio-demographic composition of the national populations, or differences in the national contexts of giving. The powerful religious effects on giving as shown in Regnerus et al. (1999) and Putnam and Campbell (2010) are, for instance, not mirrored in the British context probably because Americans are, on the whole, much more religious than Britons or because even among people at similar levels of religiosity, Americans are still more likely to give and to give more than their British counterparts. Class and income effects are strong and independent in our findings but the US research does not usually use both measures.

We also found some specific social groupings that are more generous in one way or another. Whites take the lead in joining, helping and giving but Muslims give more. In terms of class, we found the lower salariat and the self-employed as highly generous with their time and money. The most interesting finding concerns the interaction between class and income, where we find increasing class differences as incomes become lower, with the higher salariat in the poorest economic situations being the most generous, in sharp contrast to their rich class peers. One might regard this as incredible as the higher salariat are unlikely to be in poor financial situations. This is generally the case but it would not be difficult to find people in higher salariat positions but with only modest incomes, as their partners may be in poorly paid jobs or have no paid jobs at all. It could be that constant exposure to experienced or perceived poverty, whether their own or in their social milieu, incubates their generosity. It may be difficult for this group to give even more than they actually do now, but the higher salariat in the top income band (7.6 per cent of the population) could be persuaded to give more (Romney-Alexander, 2001).

There are many questions we cannot address in our present analysis. With crosssectional data, we cannot adequately explore how, when and why people adopt pro-social behaviour, and the lack of family origin information in the dataset prevents us from exploring parental effects on the genesis of generosity (Uslaner, 2008). We are currently investigating the latter issue using other datasets. It might also be the case that some groups were exaggerating their charitable donations, as has been found in organ donations (Joshi, 2011). Again we do not have administrative records from charities to check. Of course, some of the donations, such as giving to beggars, can hardly be checked. Yet the overall consistency in the patterns and trends gives us good confidence in the quality of our data and in the validity of our findings. It is hoped that our analysis in this study has enhanced our understanding of the stratification basis of generosity in Britain.

\section{ACKNOWLEDGEMENT}

I am most grateful for the generous support by the University of Notre Dame and the John Templeton Foundation Program on stimulating innovative global research in the science of generosity (Prime Grant No. 14229). This material is based upon work supported by the programme. Such support does not constitute endorsement by the prime sponsor of the views expressed in this publication. I am also grateful to Anthony Heath, Alan Warde, Mike Savage, Fiona Devine, Jorge Rodriguez and attendants at the British Sociological Association conference (2013), and at the seminar at Third

\section{File supplied to Li - Not for distribution}


Sector Research Centre, University of Southampton (2013), for helpful comments and suggestions. I am solely responsible for any errors in the chapter.

\section{NOTES}

1. Hall used several measures to support his argument, one of which is the growing number of registered charities, which reached 166503 in 1991 (Hall, 1999: 425) but this is vastly different from the 2500 for the same year, as reported in Alcock (2010: 385).

2. As our data pertain to individual giving, an important issue is whether partner's income affects decisions to give and the amount given. Prior analysis shows that it does, and that in both aspects. Thus with or without socio-demographic controls, in terms of both the propensity to give and the amounts given (absolute and relative), and among givers alone and for all respondents (including non-givers), partner's income is positively associated at the 0.001 levels. Full data in these respects are available upon request.

3. Our figures on the amounts given by all respondents are fairly close to those reported by Smith (2012: Fig. 2) on the basis of the Living Costs and Food (LCF) survey in which she finds 'almost no growth in the real level of donations since 2000’ (p. 10), with a weekly donation of $£ 2.47$ in 2010 among the general population. This is equivalent to $£ 11.15$ at the monthly level, which is only slightly lower than the lower boundary of $£ 12.68$ (at the 99.9 per cent confidence interval) in our data (the upper bound of $£ 11.15$ might reach $£ 12.68$ but no confidence intervals are shown in her data). However, the weekly amount at around $£ 9$ (around $£ 40$ at the monthly level) by donors in 2010 in her data was much higher than our monthly figure. (Even at the upper level of 99.9 per cent confidence intervals, our figure is only $£ 30.33$.) Furthermore, her data (Fig. 1) show that fewer than 30 per cent had given to charity in 2010, much lower than our figure of 72.2 per cent ( \pm .69 at the 95 per cent confidence interval) for the same period. Yet comparing with the UK Giving (UKG) data as used by McKenzie (2012), our estimate of the weekly donation at $£ 3.1-£ 4.0$ at the 99 per cent confidence intervals is compatible with the $£ 3.2$ in the upper reach of his estimate at the same level. The HOCS data thus seem closer to the UKG than to the LCF. There may be other reasons for the discrepancy in the findings obtained from different data sources. For further discussion of these issues, see Lee et al. (1995) and McKenzie (2012).

4. In terms of composition, most of the 'Nones' are Whites (96.9 per cent) but in terms of distribution, most of the Chinese have no religious affiliation (53.4 per cent).

5. It is noted here that James and Sharpe (2007) show a relative flat line when the very highly committed households (giving more than 10 per cent of their incomes) are excluded. In our data, only 2 per cent of the respondents are similarly committed, and omitting these from analysis would have no noticeable effect on the overall picture.

6. It could be that the manual working class tend to have kin living in close proximity and are thus less likely to have non-kin to help than people in higher classes. We do not have data to analyse this in the HOCS.

7. We also conducted a Tobit analysis of absolute giving. The patterns are similar to those found in the relevant part of Table 3.2 but the coefficients are bigger. The data for the Tobit models are available on request.

8. With both donors and non-donors included, people in Class 1 give 0.8 per cent more of their incomes than those in Class 7, and the corresponding figure among contributors only is 0.65 . While both are highly significant at the 0.001 level, an interesting question is whether the difference between them $(0.8-0.65=0.15)$ is statistically significant. Further analysis confirms that it is, at the 0.001 level, as it is for the difference between the other class categories in this kind of comparison.

9. One might wonder what the most generous contributors (that is, those in Class 1 and bottom income positions) are like. Further analysis shows that they are the oldest among all groups selected for the comparison (median age 59), around two-thirds of them are non-partnered, and among those who are partnered, their partners either have no incomes or have very low salaries (under $£ 10000$ ). They are also more likely to be female than their class peers in the top income bands, to have no dependent children at home, and to have long-term illness. In fact, all three bottom income groups selected for comparisons have similar characteristics. And, even though we have a very big sample in the HOCS ( $\mathrm{N}=105726)$, the size for some groups is fairly small. For instance, we have only 245 (weighted and 328 unweighted) respondents in the top class but bottom income group. But for respondents in Class 1 and in the top income band, and in Class 7 and in the bottom income band, we have very big sample sizes: 4542 and 3143 (both weighted), and the comparisons in this regard are less disputable.

\section{File supplied to Li - Not for distribution}




\section{Handbook of research methods and applications in social capital}

\section{REFERENCES}

Alcock, P. (2010), 'Building the Big Society: A New Policy Environment for the Third Sector in England', Voluntary Sector Review, 1(3), 381-91.

Almond, G. and S. Verba (1965), The Civic Culture: Political Attitudes and Democracy in Five Nations: An Analytic Study, Boston: Little, Brown.

Amato, P.R. (1990), 'Personality and Social Network Involvement as Predictors of Helping Behaviour in Everyday Life', Social Psychology Quarterly, 53, 31-43.

Attwood, C., G. Singh, D. Prime, R. Creasey et al. (2003), 2001 Home Office Citizenship Survey: People, Families and Communities, London: Home Office Research, Development and Statistics Directorate.

Banks, J. and S. Tanner (1999), 'Patterns in Household Giving: Evidence from UK Data', International Journal of Voluntary and Non-profit Organizations, 10(2), 167-78.

Bekkers, R. and P. Wiepking (2007), 'Generosity and Philanthropy: A Literature Review', available at: http://generosityresearch.nd.edu/assets/9303/generosity_and_philanthropy.pdf.

Brooks, A. (2005), 'Does Social Capital Make You Generous?', Social Science Quarterly, 86, 1-15.

Brown, E. and J. Ferris (2007), 'Social Capital and Philanthropy: An Analysis of the Impact of Social Capital on Individual Giving and Volunteering', Nonprofit and Voluntary Sector Quarterly, 36, 85-99.

CAF/NCVO (2010), 'Why do Different Surveys of Giving Report Different Findings?', Charities Aid Foundation and National Council for Voluntary Organisations.

Collett, J. and C. Morrissey (2007), 'The Social Psychology of Generosity: The State of Current Interdisciplinary Research', available at: http://generosityresearch.nd.edu/assets/10424/social_psychology_of_generosity.pdf.

Department of Communities and Local Governance (DCLG) (2010a), Our Nation's Civic Health, available at: http://www.communities.gov.uk/documents/communities/pdf/1519912.pdf.

Department of Communities and Local Governance (DCLG) (2010b), Citizenship Survey: April to December, 2009: England, available at: http://www.communities.gov.uk/documents/statistics/pdf/1543664.pdf.

Grenier, P. and K. Wright (2006), 'Social Capital in Britain: Exploring the Hall Paradox', Policy Studies, 27(1), $27-53$.

Hall, P. (1999), 'Social Capital in Britain', British Journal of Political Science, 29, 417-61.

Heath, A. and Y. Li (2014), Review of the Relationship Between Religion and Poverty, York: Joseph Rowntree Foundation.

Heath, S. and A. Dale (1994), 'Household and Family Formation in Great Britain: The Ethnic Dimension', Population Trends, 77, 5-13.

Home Office Citizenship Survey (2001-2011), available at: http://discover.ukdataservice.ac.uk/series/?sn= 200007.

James, R. and D. Sharpe (2007), 'The Nature and Causes of the U-shaped Charitable Giving Profile', Nonprofit and Voluntary Sector Quarterly, 36(2), 218-38.

Joshi, M.S. (2011), 'Whose Decision is it? Organ Donation Attitudes among Young UK South Asians', Psychological Studies, 56(1), 86-97.

Khanna, J. and T. Sandler (2000), 'Partners in Giving: The Crowding-in Effects of UK Government Grants', European Economic Review, 44, 1543-56.

Khanna, J., J. Posnett and T. Sandler (1995), 'Charity Donations in the UK: New Evidence Based on Panel Data', Journal of Public Economics, 56, 257-72.

Lee, N., P. Halfpenny, A. Jones and H. Elliot (1995), 'Data Sources and Estimates of Charitable Giving in Britain', Voluntas, 6(1), 39-66.

Li, Y. (2010), 'Measuring Social Capital: Formal and Informal Activism, its Socio-demographic Determinants and Socio-political Impacts', in M. Bulmer, J. Gibbs and L. Hyman (eds), Social Measurement Through Social Surveys: An Applied Approach, Farnham: Ashgate Publishing, pp: 173-94.

Li, Y. and D. Marsh (2008), 'New Forms of Political Participation: Searching for Expert Citizens and Everyday Makers', British Journal of Political Sciences, 38(2), 247-72.

Li, Y., A. Pickles and M. Savage (2005), 'Social Capital and Social Trust in Britain', European Sociological Review, 21(2), 109-23.

Li, Y., M. Savage and A. Pickles (2003), 'Social Capital and Social Exclusion in England and Wales (1972-1999)', British Journal of Sociology, 54(4), 497-526.

Lincoln, R., C. Morrissey and P. Mundey (2008), 'Religious Giving: A Literature Review', available at: http:// generosityresearch.nd.edu/assets/9286/religious_giving.pdf.

McKenzie, T. (2012), 'Give or Take a Few Billion: The Wide Confidence Intervals around Annual Estimates of Charitable Donations in the UK', CGAP Briefing Note 10.

Pahl, R. and D. Pevalin (2005), 'Between Family and Friends: A Longitudinal Study of Friendship Choices', British Journal of Sociology, 56(3), 433-50.

Pevalin, D. and D. Rose (2003), Social Capital for Health, London: Health Development Agency.

\section{File supplied to Li - Not for distribution}


Pharoah, C. (2009), 'Trends and Challenges in the Emerging Private, Philanthropic and Statutory Funding Environments for the Third Sector', available at: http://www.cgap.org.uk/uploads/CRESR.pdf.

Pharoah, C. and S. Tanner (1997), 'Trends in Charitable Giving', Fiscal Studies, 18(4), 427-33.

Piff, P., D. Stancato, S. Côté, R. Mendoza-Denton and D. Keltner (2012), 'Higher Social Class Predicts Increased Unethical Behavior', Proceedings of the National Academy of Sciences, 109(11), 4086-91.

Piliavin, J. and H. Charng (1990), 'Altruism: A Review of Recent Theory and Research', Annual Review of Sociology, 16, 27-65.

Putnam, R. (2000), Bowling Alone: The Collapse and Revival of American Community, New York: Simon \& Schuster.

Putnam, R. and D. Campbell (2010), American Grace: How Religion Divides and Unites Us, New York: Simon \& Schuster.

Regnerus, M., C. Smith and D. Sikkink (1999), 'Who Gives to the Poor? The Influence of Religious Tradition and Political Location on the Personal Generosity of Americans Toward the Poor', Journal for the Scientific Study of Religion, 37(3), 481-93.

Romney-Alexander, D. (2001), 'Payroll Giving in the UK: Donor Incentives and Influences on Giving Behaviour', International Journal of Nonprofit and Voluntary Sector Marketing, 7(1), 84-92.

Schervish, P. and J. Havens (1995), 'Do the Poor Pay More: Is the U-Shaped Curve Correct?', Nonprofit and Voluntary Sector Quarterly, 24(1), 79-90.

Schervish, P. and J. Havens (1997), 'Social Participation and Charitable Giving: A Multivariate Analysis', Voluntas, 8(3), 235-60.

Smith, S. (2012), Mind the Gap: The Growing Generational Divide in Charitable Giving: A Research Paper, Charity Aid Foundation, available at: https://www.cafonline.org/media-office/press-releases/2012/2109mind-the-gap.aspx.

Sturgis, P., I. Brunton-Smith, S. Read and N. Allum (2010), 'Does Ethnic Diversity Erode Trust?: Putnam's 'Hunkering-down' Thesis Reconsidered', British Journal of Political Science, 41(1), 57-82.

Tocqueville, A. (1835 [1965]), Democracy in America, ed. J.P. Mayer, trans. George Lawrence, Garden City, New York: Doubleday.

Uslaner, E.M. (2008), 'Where You Stand Depends Upon Where Your Grandparents Sat: The Inheritability of Generalized Trust', Public Opinion Quarterly, 72(4), 725-40.

Voas, D. and A. Crockett (2005), 'Religion in Britain: Neither Believing nor Belonging', Sociology, 39(1), 11-28.

Wagner, A. (2012), “Third Sector” and/or "Civil Society”: A Critical Discourse about Scholarship Relating to Intermediate Organisations', Voluntary Sector Review, 3(3), 299-328.

Wright, K. (2002), 'Generosity vs. Altruism: Philanthropy and Charity in the United States and United Kingdom', Voluntas: International Journal of Voluntary and Nonprofit Organizations, 12(4), 399-416.

\section{File supplied to Li - Not for distribution}

